\title{
Nature and the city: the salt-works park in the urban area of Cagliari (Sardinia, Italy)
}

\author{
Franco Lai ${ }^{1}$ \\ University of Sassari, Italy
}

\section{Introduction}

The question of how abandoned spaces are recovered for social uses is at the center of this article. Using the concept of a 'third landscape', I show how previously abandoned spaces can become 'lived spaces', eluding and crosscutting official planning policies and the assumed landscape degradation of post-industrial sites. At the core of the essay is the case of the Park and the Pond of Molentargius, both located in the urban area of Cagliari, the capital of Sardinia, Italy. Over the last decade, the abandoned industrial landscape of a former salt works has been transformed into an urban park, due to the intervention of environmental organizations and after a civil mobilization (Ruju 1998: 952). ${ }^{2}$ I outline how the establishment and the maintenance of the public area reconcile different social and economic interests and thus how the (apparent) irreconcilable opposition between development and protection of nature is able to find a compromise. The case outlined here sits in contrast to the growing literature in political ecology and anthropology that focuses on conflict between people and parks (West, Igoe and Brockington 2006) but it addresses the tendency for some forms of 'urban nature' to become politicised (Heynen et al. 2006).

The study is a contribution to ethnographic research that aims to uncover practices in, and representation of, places in different contexts (Koensler and Papa, 2013). People use urban parks, beaches and historical sites for leisure, sport, picnicking, etc. in their free time, and this alters how subjects share citizenship (Low, Taplin and Scheld 2005). Their 'embodied engagements' with nature (Koensler and Papa 2013) address the theme of this Special Section on human-environment relationships that go 'beyond anthropocentrism.'

The case in question is not unique. The socio-cultural transformations and the decline of heavy industry that occurred in Europe over the past sixty years have had a deep impact on the equilibrium of urban spaces. ${ }^{3}$ Many other agricultural, pastoral and industrial wastelands areas have become public parks used for leisure activities. Various industrial sites, but also open spaces such as transhumance routes, ponds and salt pans in Europe have been reconstructed and recovered. They have become part of historical, cultural and environmental heritage and are now open for the enjoyment of local communities and tourists. ${ }^{4}$ The case presented here constitutes a significant example of the complex practices of recovery present in abandoned industrial spaces. Industrial activity was transformed at the end of the salt industry into a place for recreation, and this has achieved symbolic value in political and everyday discourse.

\section{The importance of abandoned landscapes}

The march of time is signalled by the reproductive cycles of flora and fauna, visible in artefacts and ruins. In other words, we have the perception that a place, once abandoned, begins to deteriorate and falls into decay. The allure of abandoned places is to become places of dis-covery and re-covery. Concepts such as 'third landscape' and, in general, 'third space' have appeared in human geography, influenced by postmodern thought, in order to highlight how spatiality is constantly reproduced rather than taken as given (Clément 2004; Lefebvre 1991; Soja 1996). The reproduction of space highlights the complex relationship between

\footnotetext{
${ }^{1}$ Associate Professor of Social Anthropology, Department of Humanities and Social Sciences, Università degli Studi di Sassari, Sardinia, Italy. Email: lai "at" uniss.it. Thankyou to the editors and reviewers. This paper is in Koensler A. and Papa C. (eds.) "After anthropocentrism? Environmental conflicts, social movements and power," special section of the Journal of Political Ecology 20: 255-341.

${ }^{2}$ The park is well known in Sardinia, but I have reconstructed its history based on articles from the Sardinian newspapers L'Unione Sarda and La Nuova Sardegna, my own observations of the local political debate, and several websites. I frequented the park area during all four seasons through walking and photographic documentation. The months of strolling around the park area have been useful as a basis for more systematic research; see Ingold and Vergunst (2008: XI) on doing "ethnography (...) on foot" and "walking as a technique of ethnographic research."

${ }^{3}$ In particular, in Sardinia, the abandonment of agro-pastoral activities and extraction of raw materials (mining, salt, etc.) has raised the issue of safeguarding the hydro-geological balance and nature conservation as a form of public intervention, aimed at restoring and maintaining the structure of the landscape not only in aesthetic and historical terms, but also materially and geologically. Land abandonment is capable of producing imbalances in geological structures in the medium and long-term (Ruddle and Manshard 1981; Blanchemanche 1990). In Italy, the perverse effects of poor land management and the absence of a long-term strategy by the political administration add to the process of social, economic and territorial change (Settis 2010).

${ }^{4}$ In Sardinia the case of mines is emblematic (Atzeni 2011); also abandoned railway trails (Sistu and Perelli 2011).
} 
physical space and its social use, which elude linear, dichotomous opposition between abandonment and institutional and/or public planning of recreation areas. According to Soja (1989: 80), "spatiality (i.e. socially produced space) is a substantiated and recognizable social product." Elaborating Lefebvre's thoughts on the production of space (Lefebvre 1991), Soja proposes the notion of "third space" to delineate those "lived spaces" which overlay physical space and are neither institutionally organized nor 'mental' or 'physical.'

In a more incisive vein, Gilles Clément's concept of 'third landscape' is a useful tool for the understanding of re-used and abandoned places (Clément 2004). Beyond the rather open and inclusive character of this concept, the residual nature of the space abandoned by agriculture, industry, etc. is interesting. These 'third landscapes' are not rebuilt, or subject to conservation and heritage policies. They have an 'undecided' nature. Reconstruction costs could be high and too expensive to justify, or they are not deemed to be significant for conservation planning. They are spaces that are formed 'by subtraction' from the recognized human-environment assemblage. These areas, in short, are places of 'scrap, waste, margin.' In these spaces, however, recovery of the flora and fauna are still possible (Clément 2004). A process of spontaneous 're-naturalization' reflects the traces of the previous structures.

Rural landscapes are places planned and equipped; they constitute 'specialized ecosystems' aimed at production (Fleury and Mollard 1976). An abandonment of economic activities brings about the slow decay of production capacity and agricultural relics. This is evident in Mediterranean Europe with its terraces, farm buildings and other artefacts. In Sardinia, the shelters of shepherds and farmers, built in dry stone and covered with branches, become overgrown by vegetation in just a few years and fall into disrepair if fully abandoned. Hydrological landscapes, including the wetlands created by ponds and salt works in coastal areas, may appear today as 'wilderness,' but in the past they were organized and equipped for economic activities such as salt production, fishponds and stockbreeding. Since they are attractive areas for birds, they are popular for hunting.

The drive to conserve can result in creation of protected areas and parks in some of these territories. This form of political intervention has often been able to mediate between the various local stakeholders, or representatives of economic interests that gravitate to the area. The establishment of a park is generally designed for tourism and sports, scientific research, the protection of ecosystem plant and animal species, but also to manage this same ecosystem, as can be seen in the case of wetlands of Doñana in Andalusia (Spain) and the Camargue in Provence (France) (Ojeda Rivera 1983; Picon 1988). Once they have become a park, their technical efficiency is maintained, at least to some extent. But in the case of wetlands areas not subjected to protective intervention, the scenario that emerges is a slow abandonment, as in the case of the land reclamation described by Gabriella Da Re (2009) or the case of the palù (swamp) studied by Nadia Breda (2001) in Northern Italy. This wetland area in Veneto is a bocage landscape and is characterized by the presence of spring water.

The proliferation of wastelands, in a region such as Sardinia, is related to processes of social change that occurred since World War II. These processes can be summarized as follows;

- migration from rural and pastoral regions leads to the abandonment of farming and the pastoral economy, the expansion of uncultivated and wild areas, and the slow disappearance of livestock transhumance;

- the migration from rural villages to coastal industrial major cities; the proliferation of tourist facilities along the coast;

- increasing urban population, the expansion of cities and the 'invasion' of urban agglomerations into nearby agricultural areas;

- the progressive abandonment of mines and mining settlements.

The abandonment of the landscape is often interpreted as a metaphor for Italian history in recent decades, and as the result of the indifference of politicians (and of the Italian people), permitting poor land management and 'ugliness.' The lack of care is certainly visible today in Sardinia as in the rest of Italy (Piermattei 2013, this volume). ${ }^{5}$

\section{The salt works area and the birth of the park}

In the city of Cagliari, there are now areas considered as 'natural spaces' that have previously been industrial landscapes, including salt works. These spaces were part of a highly structured system until a few decades ago and are now abandoned after the cessation of salt production (Pira 2004; Sanna 2004). The area, located between the coast and the cities of Cagliari and Quartu S. Elena, has now become a park that includes Molentargius Pond and the former salt works (Figure 1). This is an area that the population was already

\footnotetext{
${ }^{5}$ The campaigns of the Italian Environment Fund (FAI) called 'The Places of the Heart' are one effort counter this trend. See www.fondoambiente.it (the official webpage of the FAI) and www.iluoghidelcuore.it [Accessed March 10, 2011].
} 
utilizing as a 'green' space before it officially became a park, just like the nearby headland of Cape Sant'Elia, formerly a military property. People enjoy places close to residential areas which, although compressed by urban and industrial development, are perceived and experienced as natural areas (Attané 2008; Barthélémy and Nicolas 2008). Family cyclists, runners, and birdwatchers, enjoy them as places of nature in the middle of the city, especially on sunny days.

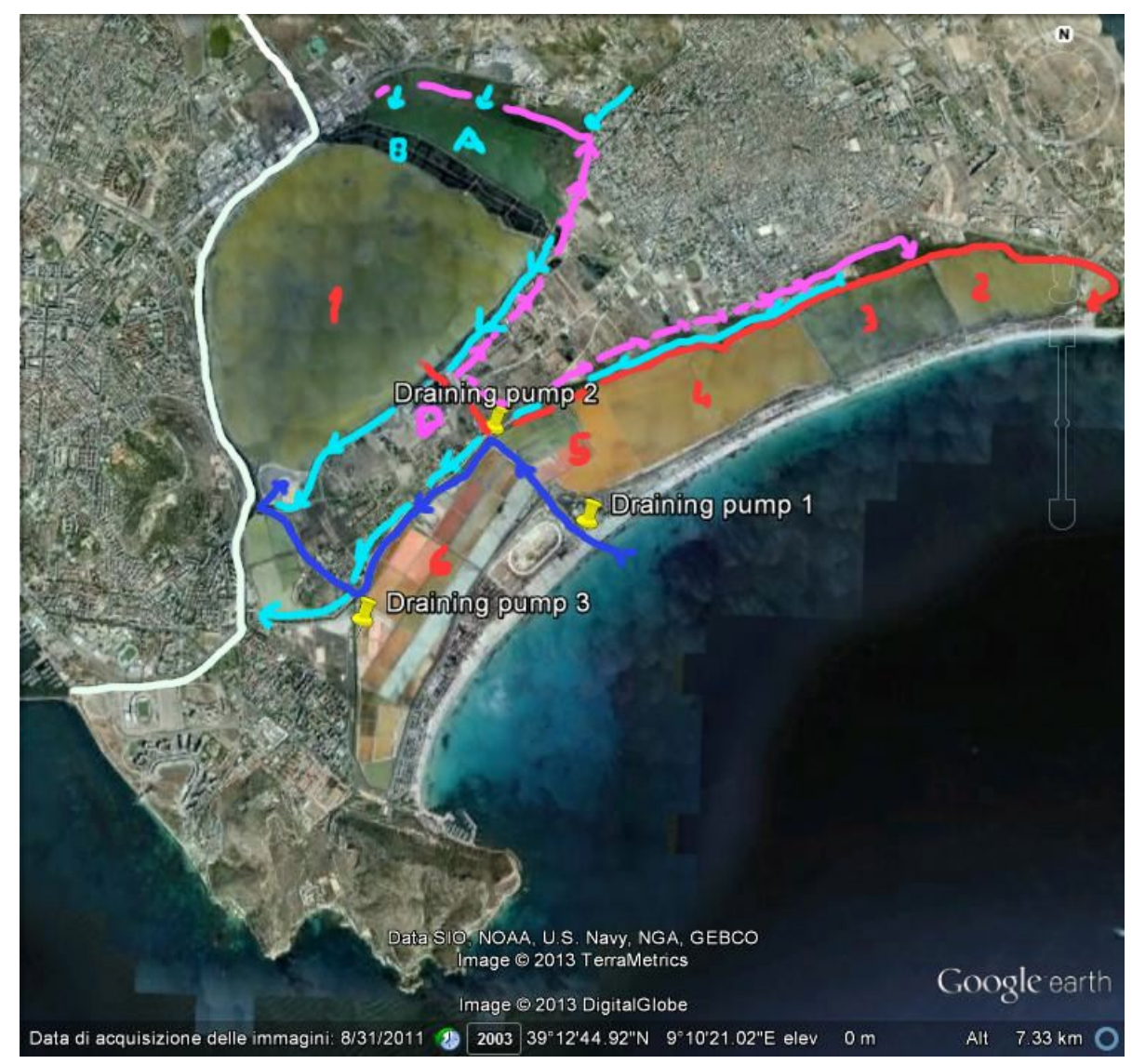

Figure 1: The flows of salt and fresh waters. White line: the main canal from the Mediterranean sea; Salt waters: purple line: from the sea to the first evaporation pond ("Molentargius"). Red line: from the pond to stages of evaporation and to the settling tanks 2-6; fresh waters: pink line: from the purification plant D to the artificial lake A ("Bellarosa minore") and to the other artificial lakes; blue lines: from the artificial lakes to the main canal (white line); B: filterer ecosystem. Blue arrow: creek outflows in basin A. Sources: Google Earth; Mori 1950; www.parcomolentargius.it; www.apmolentargius.it.

\section{Establishment and salt production}

The salt works of Cagliari were at the core of European and Mediterranean economies in modern times. These salt works and ponds look 'natural' only at first sight. The entire landscape was highly organized to support the salt economy. There was a system that connected sea, shore, salt works and ponds, canals and routes to shipment from the port in Cagliari. The present-day park area yielded a harvest of salt since ancient times, but the area was 'natural' until the early 1830s when the main canal that connects the different areas was built (Pira 2004). After this it was transformed into a rationalized space of industrial production. In the 1930s the Italian government improved the salt production infrastructure, creating a highly specialized environment with a range of technological innovations. Like similar systems in Mediterranean Europe, water flowed from the sea toward the basin for evaporation via a canal network. It worked as follows: 
- salt water flowed from the sea to the draining pump, along the canal up to the pond (the first evaporation basin);

- these waters then ran toward the basins for the next stages of evaporation;

- from here the system of canals and sluiceways conveyed the highly saline waters to the settling tanks. In these basins workers gathered up sodium chloride and further extraction yielded bromine and potassium salts from the residual salt waters, which were returned to the sea at the end of the production process.

Heynen et al. claim that "The urban world is a cyborg world, part natural/part social, part technical/part cultural, but with no clear boundaries, centers, or margins" (Heynen, Kaika and Swyngedouw 2006: 12). This helps to explain the nature of the link between the urban area of Cagliari and the salt works. The presence of an existing lake was important because it was converted into the first evaporation basin. According the Italian geographer Alberto Mori (1950), salt production is like agriculture. It follows the rhythm of seasons and it is labour-intensive. Some environmental conditions are important: climatic conditions (high wind speeds and temperature), proximity to the sea and a port, and the availability of labour (south Sardinia's population density is higher than the rest of the island). These conditions explain the presence of salt works in the Cagliari urban area. Throughout modern history the salt works used forced labour. Between the nineteenth and the twentieth century the inmates of the nearby penal colony worked in the salt works under harsh conditions, often contracting malaria. Malaria was common until the anti-malarial post-war campaign funded by the Rockefeller Foundation in the 1950s.

The birth of the Italian State (the Risorgimento, 1861) placed the park salt works in government ownership, and later it was controlled by the Minister of Finance. At the beginning of the 1900s production became mechanized with electricity and a railroad (Mori 1950, 1970). A guide from the Italian Touring Club of 1918 (TCI 1918: 110-111) describes in a succinct but detailed way the elements of interest of the salt works: the direction and production buildings, and the homes of employees. It focuses in particular on the industrial equipment and sewage works.

At the end of the 1960s the State salt works measured 852 hectares and production reached 200,000 metric tonnes (220,000 tons), with overseas exports (Mori 1970). During the 1960s and 1970s salt production then declined, mostly due to increasing economic competition from other national and international plants (Pira 1994).

The configuration of urban space changed around the salt works over the centuries. In the years following the end of World War II, Cagliari did not grow far outside its historic districts (Figures 2 and 3). But between the 1950s and 1970s its residential areas expanded. From 1951 to 1981 there was population increase, as well as a rising birth rate. During this period growth in the four municipalities around the salt works was consistent. Cagliari and Quartu Sant'Elena, the second town close to the park, became the most attractive areas for rural-urban migration. Cagliari now has half the population of the province and one fourth of the total population of Sardinia. In this period of rapid and chaotic urban development the areas surrounding the salt pond were built on, sometimes without planning permits, and farms and abandoned fields were incorporated into the city (Principe 1981: 186; Pira 2004: 380; Gatti and Puggioni 1998: 1051). There is now a residential area between the cities of Cagliari and Quartu right in the area adjacent to the park. Houses, small farms, craft workshops, and horse riding are now just a few meters away (Figure 3). This area has been cultivated from since medieval times but today it is very difficult to identify the vestiges of the past. According to the historian Gian Giacomo Ortu this area is a real "tiers paysage", a Third landscape (Ortu 2011: 141-147). Population growth has flattened in recent years due to a decrease in the birth rate (Figure 4). ${ }^{6}$

I talked to some people aged 65 who remember this area being farmed intensively until the 1960s. There are several volumes documenting the history of urban space up to the years preceding the outbreak of war, a time that the Italians will remember as carefree and optimistic. ${ }^{7}$ Although more than sixty years has passed since then, the speed and strength of the transformation process is documented in the photos of those years, showing the original aspects of the surroundings of the city, an area that is much changed today.

\footnotetext{
${ }^{6}$ The total population of the municipalities (Cagliari, Quartucciu, Quartu Sant'Elena, Selargius) that host the park (at the 2011 population census) is 260,688 inhabitants, about half the entire population of the province of Cagliari (550,580 inhabitants, and Sardinia 1,672,404). From 1951 to 2011 the total population of the four municipalities increased from 160,567, and the town of Quartu St. Elena grew considerably from 17,579 to 69,296. Source: www.istat.it [Accessed January 30, 2013].

${ }^{7}$ In the debates of the last election campaign for the election of the mayor of Cagliari (May, 30, 2011), the two candidates mentioned in their manifestos a priority management area between the coast and the Park Poetto Saline - deemed central to the tourism policy and environment, but also to the shared social life of the town. The national press has dealt with the case with interest (cf. Turano 2011).
} 
Even when, at the beginning of the twentieth century a municipal beach was established with the first bath-houses, the salt works maintained their distance from it. The salt works were a district with a distinctive architecture, with buildings for employees and executives, and even its own church and theatre (the theatre has become part of the city's cultural life only recently). It was a settlement resembling a nineteenth century British "one company town" (Masala 1994). A Touring Club guide from 1954 (TCI 1954: 34-35) shows a photograph of the salt works along with other images of a growing seaside and tourist resort. The old picture postcards call the salt-work scenery 'Picturesque Sardinia', but the descriptions contained in these guides show a production site with 'modern equipment' and they parade its massive production capacity. So sixty years ago the salt works were still considered marginal, separated from the city, at least from the tourism standpoint (Sanna 2004).

The official explanation for the abandonment of production at the Italian State salt works was pollution from urban sewage. In 1984 production was halted. By contrast to the west of the site there is a vast area with ponds and private salt works, still in operation today. ${ }^{8}$

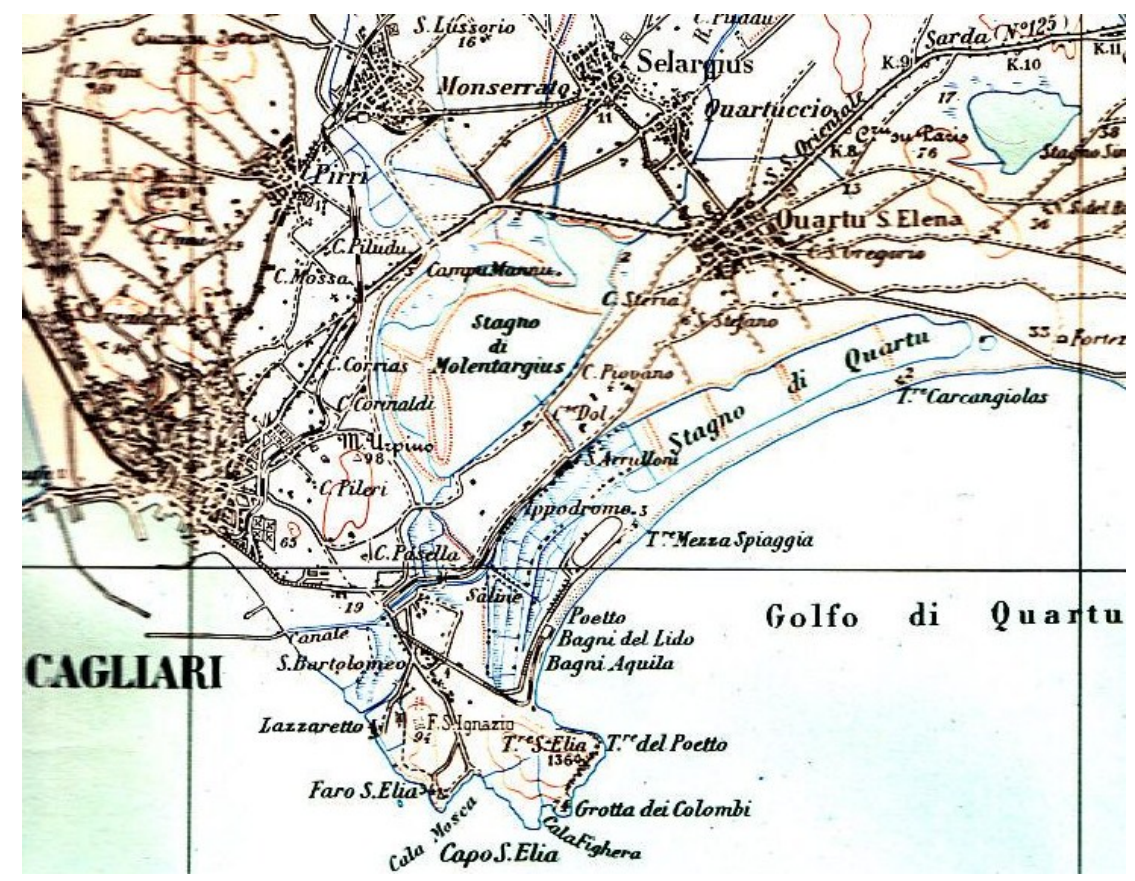

Figure 2: The urban area of Cagliari, the ponds and the salt works in the 1930s (Source: Istituto Geografico Militare, Cagliari F. $\left.{ }^{\circ} 234,1: 50,000,1931\right)$.

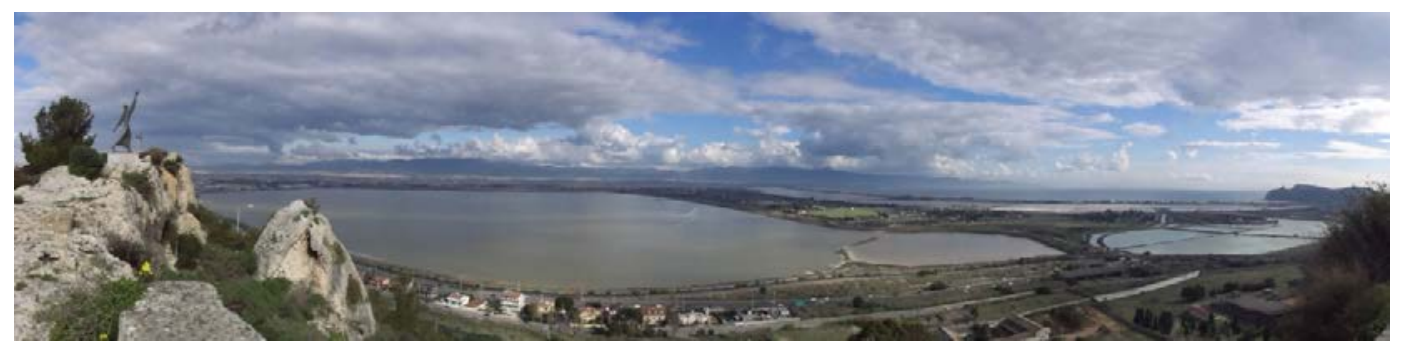

Figure 3: A view of the park area: the ponds, the salt works and the Mediterranean Sea in the distance (author, 2012).

\section{Park establishment}

The preservation of a wild place in the middle of an urban area has now become a resource for the population, but capturing this resource has a long history. A stimulus for its preservation was when the

\footnotetext{
${ }^{8}$ Saline Conti Vecchi S.p.A. (http://www.contivecchi.it, accessed February 25, 2013), an enterprise founded in 1929.
} 
Ramsar Convention of February 2, 1971 was passed for the protection of wetlands of international importance. The Ramsar Agreement was implemented much later in Italy with a decree by the President of the Republic (11 February 1987, No. 184).

In the mid 1980s, with the end in salt production, various environmental associations, members of the local intelligentsia, and scholars in Cagliari proposed the creation of a park at the salt works. Environmental groups like the World Wildlife Fund for Nature (WWF), local associations such as the LIPU (Italian League for the Protection of Birds), the Environmental League, representatives of cultural organizations and the university, were all in support. The Association for the Park Molentargius was established in 1988 and became a pressure group. In Italy the presence of multiple stakeholders in policies governing the establishment of parks has meant there is a need for negotiation with political actors and the local population (Beato 1999; Piermattei 2013). Fortunately there were no strong building and construction industry interests hoping to redevelop the site, although these have certainly been strong in other Mediterranean and Italian parks. ${ }^{9}$ The social and institutional actors involved were all environmental organizations, local politicians or local government, without strong opposition from business interests.

In 1999 the campaign was successful, and the 1,600 hectare Regional Park of Molentargius was established thanks to an agreement between the Sardinia Region, the Province of Cagliari and the four surrounding municipalities (Cagliari, Quartu Sant'Elena, Selargius, Quartucciu). ${ }^{10}$ Its establishment was a complex matter, reflecting issues that are common in Italy; land ownership and responsibility for infrastructure works. After the establishment of the Park, its opening was ultimately delayed by nine years, and it finally opened to the public in 2008. In the intervening period before its official opening many people frequented the site, entering through a 'secret passage' - a gap in the wire-net fencing. Certainly the fifteen years that separate the end of salt production from the establishment of the park, and the eight years of unofficial entry, made the site a 'third landscape' in Clément's terms. Today the artificial salt works ecosystem infrastructure (canals, dams, tanks, salting, etc.) are still there although abandoned. They are still able to support production if there was new investment. However some equipment has gone, and so have the large piles of salt that at one time were visible from several miles away.

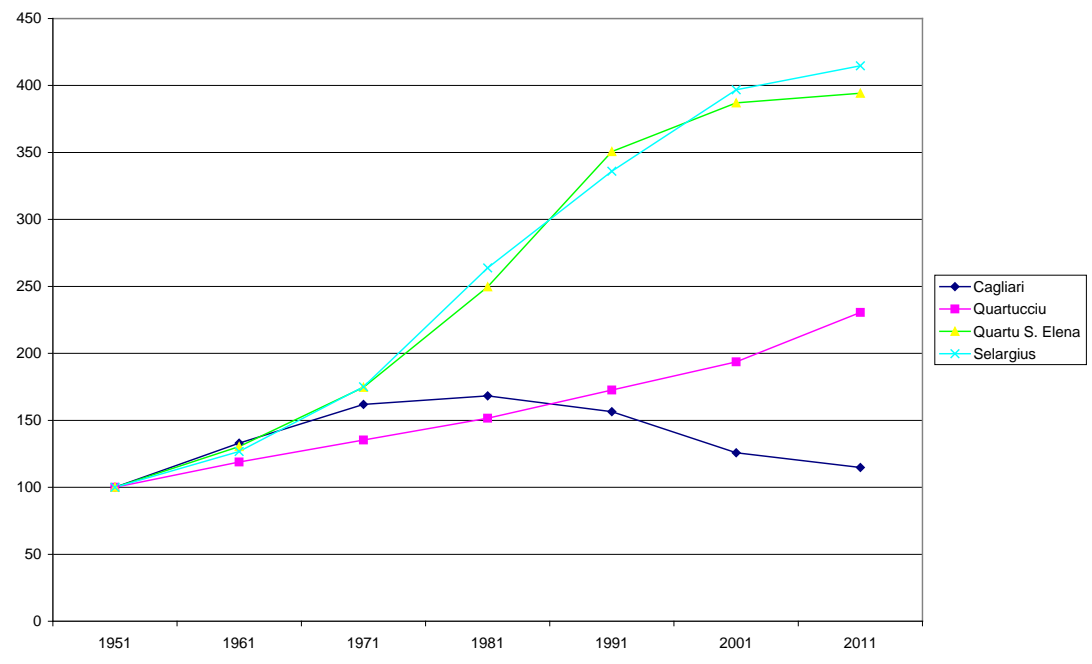

Figure 4: The population of the park area, 1951-2011 (Indexed, 1951=100). Source: ISTAT.

Walking through the park today reveals a high degree of structure and organization. The salt works were a highly planned space, both in the production process and the delicate interaction and balance between its parts: the sea, the pond just in front of it, the water supply channels for salinity adjustment, and the settling tanks. The salt works are rather inaccessible for visitors, but they are of great interest from a technological point of view.

Today, the 'third landscape', resulting from of a process of 'naturalization', has significant other attractions. The ponds are a natural oasis for Mediterranean wetland bird species; a safe area for sedentary and for migratory birds (Figure 5). Ornithologists and observers can see different species from close up, in a

\footnotetext{
${ }^{9}$ In the case of the Park of the Camargue in southern France there was a mediation with local business groups (Picon 1988). See also Breda (2001) and Ojeda Rivera (1983).

${ }^{10}$ Regional Law February 26, 1999, No 5, Establishment of the Regional Park Molentargius-Saline.
} 
'natural' environment just within the city. And visitors on foot or bicycle can get to the beach, a quiet place, where the only sounds are the wind, the ocean, and birds (Figure 6 and 7).

The park authority found the water circulation systems needed repair and cleaning of the channels. Work was funded by the Ramsar Convention and the Italian State, ending in 2005. Since then there have been problems in securing funding for park staff, and developing a shared plan for long term management. There was also the complex issue of transfer of authority between the Italian State and the Region of Sardinia. Salt production in Italy belonged to a State Monopoly until February 2008, and afterwards the salt works and all its buildings passed from the State to the Region. Other problems to be solved, central in the creation of the park, were the removal of the pylons and $12 \mathrm{~km}$ of high voltage wires across the pond (completed in 2007) and the presence of large groups of stray dogs, frequent fires, water pollution, illegal building, the illegal dumping of waste (building materials, abandoned appliances, cars, etc.). There was also the presence of a new urban district at Is Arenas which had developed spontaneously, as already mentioned. There were also debates over how to manage the park, including the role of local government administration.

The result was that on September 24th, 2008 the park opened to the public.

\section{Current uses}

On its web site the Park management expose the main problems of managing a protected area within an urban setting. In the language used in the extract below it is clear that the cultural setting and a philosophy of environmental protection directs management activities, guided by scientific advice, public institutions, and financial means;

With the establishment of the Park and the start of its operation since June 2006, the territorial planning of Molentargius opens new perspectives, mainly oriented to the enhancement and preservation of the environmental system to be intended as a resource to develop, monitor and protect in all its aspects. The Park of Molentargius is a natural system of extreme environmental importance. The human pressure that has always interested this area creates great difficulties for the management and administration of the system as a whole (...). The two different requirements have generated phenomena such as the uncontrolled illegal housing in the area of Is Arenas and the general tendency to regard the area as a place capable of forms of degradation and neglect. (...). Since the beginning of its activities, the Park Authority has expressed an interest in promoting sustainable development, retraining and enhancing the area's environmental resources. In particular it aims to recover the historical activities related to salt production and development of new activities compatible with the natural values; its fruition and its opening to the scientific community are two other strong points in the process of redevelopment. Since the Park has established, a number of initiatives are taking place in science, in the management field and in the field of fruition, reflecting the new willingness to consider Molentargius no more as an area "closed" from constraints, unfortunately often redundant and almost never observed, but rather as a resource to share, the potential of which stem primarily from the environment and by his own position in relation to urban areas. ${ }^{11}$

The civil society 'Association for the Park Molentargius', working with park management, holds a pragmatic view of the protection of nature and highlights the role of awareness-building through environmental education initiatives and scientific research. The idea of nature as an 'asset' is not employed dogmatically, but must take shape through a process of participation and sharing, as other studies have pointed out (Cloarec 1995; Heatherington 2010; Siniscalchi 2002; Ythier 1995). The Association works with several local representatives of national environmental groups (such as the Environmental League, Italian League for Bird Protection, LIPU, Italia Nostra and WWF Italy), along with academics in the city. In Italy associations and their movements are formed to support local environmental issues specific to a given area, and this has been documented elsewhere (Strassoldo 1993). During the decision process that led to the establishment of the park, the Association promoted a local political debate about the use of the area. Environmentalists and academics supported the activities such as tourism, research, education projects and several productive activities compatible with sustainable development. In this case, environmental groups have had a proactive role and their commitment did not end with the achievement of the designation of the park. In particular, they intend to work on environmental education and support for the protected area, as well as participating in scientific research.

Since its foundation in 1988, the Association has proven to be a proactive organization, capable of involving the energies from traditional environmental groups and from all the other stakeholders who care about the fate of this area;

\footnotetext{
${ }^{11}$ http://www.parcomolentargius.it [Accessed July 30, 2011].
} 
If the objective of the Regional Park has become a reality, and if this reality has become possible for large segments of the population and the hinterland of Cagliari, this happened because every popular and educational activities, but also science, has never been disconnected from the main goal: to make known the importance of the pond and make it accessible to all. This has helped create a large popular consensus around the ecosystem, and a growing awareness of the inestimable value that assumes the Molentargius not only for the Cagliari area, but for all the environmental and cultural heritage of the Mediterranean. ${ }^{12}$

The park authority has now reactivated the water circuits to obtain a better balance between water purification, levels of salinity, flora and fauna. A 'filterer ecosystem' basin is a small wetland that functions as a phytodepuration system. ${ }^{13}$ The Park authority has also activated a circuit for the recycling of creek water and urban wastewater. The creeks run into the pond; urban wastewater is piped into a purification plant. Both flows drop into the canals flowing outward towards the sea or towards the park basins. The re-establishment of this delicate and artificial ecosystem is the precondition for the possible revival of salt production on a small scale, and provides suitable conditions for the bird population (Figure 1). ${ }^{14}$

In summer 2011, the flamingo population nesting in the park was one of the largest in recent years. ${ }^{15}$ The inhabitants of Cagliari and tourists could observe from the city's best vantage point, Monte Urpinu. Thousands of flamingos massing along a stretch of land devoid of vegetation could be seen from a protected location. A pink cloud stood out clearly from the surrounding soil. Other small groups of flamingos are found along the banks, close to the freeway that runs through the city or standing on the concrete bases where the high voltage pylons used to run through the centre of the pond.

I did not notice until 2012 the presence of tour buses that stop to allow tourists to observe and photograph the various pink clouds of flamingos. I had not even noticed that those same buses stop along the road that runs along the salt pond and the Poetto beach, to allow tourists to see the flamingos from close up as they are feeding in the pond. It is a popular sight - one man got out of his bus with a camera saying "It's amazing!" The scene is stunning and unusual, as there are so many birds. Flamingos also feed in another pond located in the southeast of Cagliari, as well as in another in the southwest on the outskirts of the city, its commercial port and its industrial area.

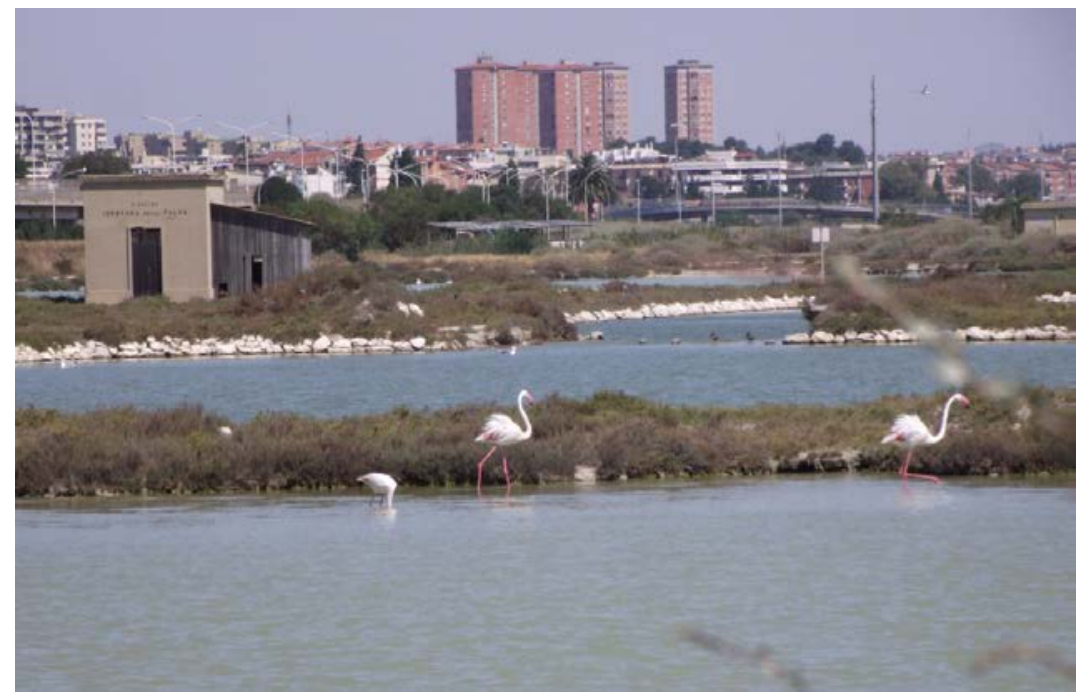

Figure 5: Flamingos in the pond, and the city of Cagliari in the background (author, 2011).

\footnotetext{
${ }^{12}$ http://www.apmolentargius.it [Accessed July 30, 2011].

${ }_{13}$ Phytodepuration means water filtering and purification through sedimentation, precipitation, adsorption, assimilation by plants, and microbial activity - artificially recreating the same ecological conditions as in natural wetlands. http://www.life.trelaghi.it/files/inglese/5_fitodepurazione.pdf [accessed May 21, 2013].

4 Cf. Mori 1950: 56-57; Corti 2004; Pira 2004; Sanna 2004; Cocco 2010; http://www.apmolentargius.it, http://www.parcomolentargius.it [accessed February 2, 2013].

${ }^{15}$ The scientific name of the Mediterranean flamingo is Phoenicopterus roseus.
} 
The city of Cagliari is surrounded by several prohibited areas, due to the presence of military zones, especially near the pond area. One of them is the promontory of Capo. S. Elia, which juts out into the Gulf. A part of the headland is home to a military installation. The whole area contains a number of military barracks and it is close to the beach and marina. The armed forces have gradually abandoned this area, and as a result it has become another 'third landscape' within the municipal boundaries, progressively being used for walking tours and other leisure activities.

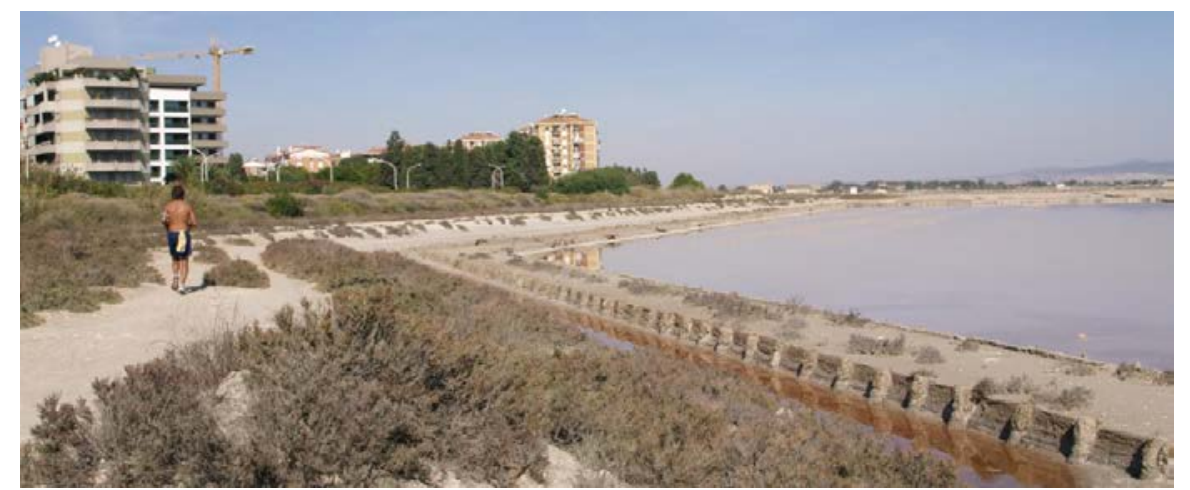

Figure 6: A runner on the salt works banks, with a residential area on the left (author 2011).

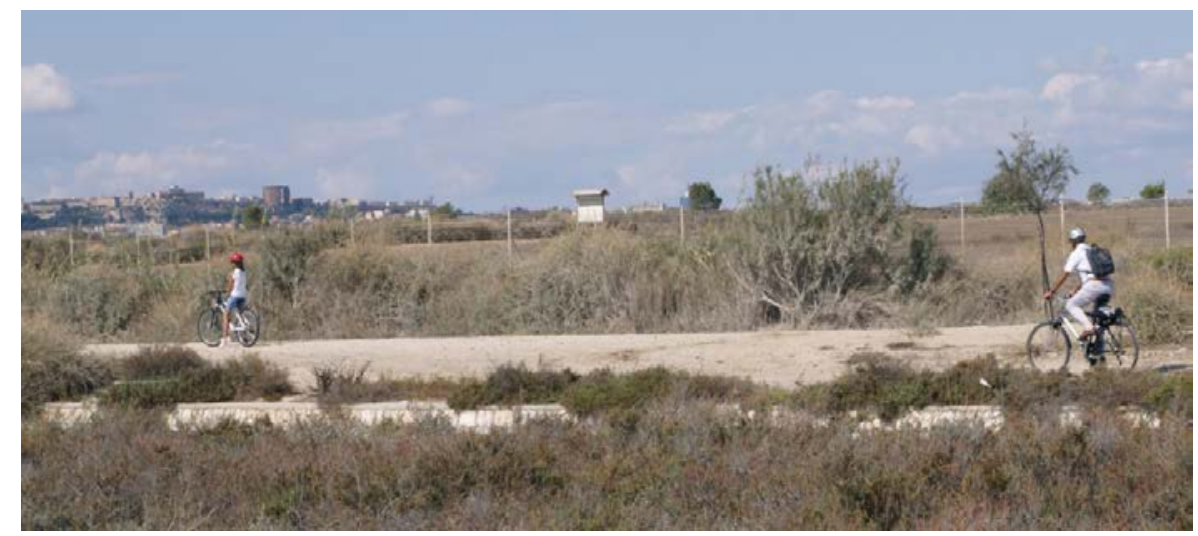

Figure 7: Bikers on the park road with the city in the background (author 2011).

For sports and hiking, the 'Saline Park' and other portions of these 'third landscapes' are areas of discovery and places to undertake creative activities like photography, observing, and running. These are places of discovery, to explore and to be appropriated as part of one's living space, in different ways (De Certeau 1990). There are for instance, many athletes who train on the roads and the banks. Entire families visit the park on their bicycles or they rent them at the park headquarters. One of the buildings has canoes and many fans of this sport can be seen around the canals with their kayaks. Other people take dogs for a walk, or visit the park along the canals on boats. The management of the park itself organizes guided tours, and there are places reserved for bird-watching. Even on the hottest days of summer and on Sundays the park is now well patronized. Secondhand goods markets are held every Sunday and are very popular; among all the objects, old postcards of Cagliari and Sardinia are much sought after. Every year when the FAI (Italian Environment Fund) organizes visits to monuments and sites of historical and environmental interest (those normally not allowed public access during the rest of the year) they are always sold out. In this way, abstract collective heritage is made real to small groups. The buildings also contain collections of photographs taken during the summer at the beach. And the beach is one of the places of the city that best represents socialization practices.

Currently, the managers of the park are planning to resume the manufacture of limited quantities of quality salt and to offer thalassotherapy treatments. The proposal to restart production met with unanimous approval, because the salt industry is perceived as sustainable in environmental terms, running a production process based on the water of the sea and the sun. The current state of neglect is therefore relative, and set to change gradually over time. 


\section{Representation}

Angius offers a vivid description of the salt pond located south-east of Cagliari in the 1830s;

It is truly magnificent wandering around in these waters in sunny days, observe the flamingos [...] the flocks of swans, of codons, the tufted, and other species of ducks, of gulls, the flight of the crows, of the eagles, wandering in all parts for when browsing with the speed of lightning swoop and dive and drag the prey between the claws, and when, as is usually the eagle rests upon a pole to tear. (Angius 2004: 60-61) [1833-1856].

The large and varied bird life that the author described 180 years ago, before the canals were built, constituted an important resource for the city along with the wildlife of the forests in nearby mountains. A few decades later, Alberto Della Marmora also noted an abundance of resident and migratory birds that inhabited the ponds of Cagliari (Della Marmora 1997 [1860]: 184). The southwest pond was also an important resource for fishing in the lagoon (Angius 2004: 57-71).

The birds have become a characteristic element in the public representation of the city. "It is amazing to have a place like this in town", one member of a group of mountain bikers said to me. In summer, groups of tourists passing through the park stop along the road to observe the many flamingos in the water of lagoons (stagni) and by the salt pond. The flamingos use this area as a stop-off on their migration between Africa and the Camargue region of France. We find an image of the park's flamingos in the foreground with the city in the background on advertising hoardings, on the covers of books, in travel magazines, in tourism advertising, on television, and on shop signs. The image has historical continuity, and also has ecological significance as shown by the exhaustive reconstruction of Marinella Lörinczi (2002). In the campaign for the municipal elections of Cagliari in 2011, the candidate for the center-left, Massimo Zedda, used this same image of flamingos flying against the backdrop of the city carrying the sign 'Cagliari soars.'

The park is a partially 'domesticated' space and it is nonetheless perceived as 'natural' by the presence of its birds and aquatic fauna. The presence of avifauna was also the main reason for the Ramsar Convention listing in 1971; for the same reason the European Union decreed a Special Protection Area (in 1979) and a Site of Community Importance (in 1992). The very institution of the park uses a guiding principle of shared collective heritage, with scientific input. The collective heritage is represented as a common good, as a legacy of the past (the built space) and of nature. This does not exclude a different kind of representation: the 'sensory', 'emotional' and contemplative one, with a nature made by the community and its many users (Lenclud 1995; Milton 2002).

\section{Conclusion}

The 'undecided' characteristic of Clément's 'third landscape' enables the free uses of these public spaces. In Cagliari, people took informal possession of the space after the abandonment of salt production. Researchers, environmentalists, and local and park authorities believe that the optimal management of this delicate ecosystem should make sustainable development possible, with ecological tourism (bird-watching, industrial archaeology), and the revival of the salt economy. ${ }^{16}$ In short the Park is an institution where different social and economic interests are coexisting and finding an opportunity for agreement. Moreover the Park is an institution that has to ensure the maintenance of the ecological system by decree (Lascoumes 1994; Dubost and Lizet 1995). The everyday ways in which people use and inhabit this open public space effectively legitimate the Park.

For many people, especially runners, bikers, bird watchers or photographers, the environs of the park were popular even before its official opening. These unofficial ways of appropriating a space were part of the 'third landscape.' But as the rehabilitation of the area advances in the future, the area will probably lose the characteristics of a 'third landscape' to resume, at least in part, some new productive functions and, simultaneously, to become a space where the elements of 'naturalness' - the local flora and wildlife - are actively preserved. Along this trajectory, the irreconcilable (and apparent) opposition between development and protection of nature must find a compromise. The spontaneous and relaxed (or 'slow') way in which the inhabitants of Cagliari spend their spare time have laid the foundations for sensitivity to an area that otherwise would have degraded further. But it was the mobilization of social movements, political actors and representatives of the local culture that drove the debate on the establishment of the park. From this perspective, the park developed from a shared process, rather than being created in a top-down fashion, as has happened in other cases where local populations were not in agreement or felt threatened (West, Igoe and Brockington 2006). The main difference from the many examples of disputes arising from the establishment of protected areas and natural/national parks is that no land was taken from the local inhabitants, and public access is still available to most of the site: it has not been privatized and it is not exclusionary.

\footnotetext{
${ }^{16}$ As expressed recently at the conference Una rete di aree protette nel Golfo degli Angeli. Turismo ambientale e buone possibile di sviluppo nelle zone umide, Cagliari, January 19, 2013.
} 
In this article, I have attempted to show the complex dynamics of the relations between spatiality and social life through the use and reuse of landscapes in a unique setting. The notion of 'third landscape' has been useful in highlighting how localities can become 'lived spaces' again, cutting across official planning policies and avoiding the environmental degradation common in abandoned post-industrial landscapes.

\section{References}

Angius, V. 2004. La Sardegna paese per paese. Vol. 3. In La Sardegna paese per paese, Cagliari: L'Unione Sarda. Pp. 9-354. [original edition: G. Casalis (ed.) 1853-1856. Dizionario Geografico-StoricoStatistico-Commerciale degli Stati di S.M. il Re di Sardegna. Torino: Maspero].

Attané, A. 2008. Pêcher, courir, trier ses déchets... pratiques de l'environnement ou rapport rapport aux autres? Ethnographie comparée des pratiques de l'environnement dans deux villes françaises (Cherbourg et Martigues). Europaea 1-2: 261-282.

Atzeni, P. 2011. Paesaggi della cura, paesaggi vitali. Territori e ambienti minerari della Sardegna. In F. Lai and N. Breda (eds.) Antropologia del «Terzo paesaggio», Roma: CISU. Pp. 75-96.

Barthélémy, C. and L. Nicolas 2008. Pêcheurs amateurs du fleuve à la mer. Des pratiques ordinaires de nature au défi de la gestion environnementale. Europaea 1-2: 283-301.

Beato, F. 1999. Parchi e società. Turismo sostenibile e sistemi sociali. Napoli: Liguori.

Blanchemanche, P. 1990. Bâtisseurs de paysages. Terrassement, épierrement et petite hydraulique agricole in Europe XVIIe-XIXe siècles. Paris: Editions de la Maison des Sciences de l'Homme.

Breda, N. 2001. Palù. Inquieti paesaggi tra natura e cultura. Verona-Treviso: Cierre Edizioni/Canova.

Breda, N. 2002. Against the landscape: landscape, perceptions, inversions in a land which is no longer a land. Europaea 1-2: 385-407.

Clément, G. 2004. Manifeste du tiers paysage. Paris: Éditions Sujet/Objet.

Cloarec, J. 1995. Un village se penche sur son paysage. In C. Voisenat (ed.) Paysage au pluriel. Pour une approche ethnologique des paysages. Paris: Editions de la Maison des Sciences de l'Homme. Pp. 195208.

Cocco, G.B. (ed.) 2010. Paesaggi d'acqua e flussi audiovisivi. Sperimentazione per il progetto di architettura e di paesaggio nel sistema ambientale Molentargius-Saline a Cagliari. Rome: Gangemi.

Corti, E. 2004. Identità storiche e priorità progettuali. In G.G. Ortu (ed.) Cagliari tra passato e futuro. Cagliari: CUEC. Pp. 355-375.

Da Re, M.G. 2009. Residui di memorie. In M.G. Da Re (ed.) Le vie dell'acqua. La bonifica di Arborea. Quartu S. Elena: IGES. Pp. 7-14.

De Certeau, M. 1990. L'invention du quotidien. Tome 1: Arts de faire. Paris: Gallimard.

Della Marmora, A. 1997 [1860]. Itinerario dell'isola di Sardegna. I vol. Nuoro: Ilisso.

Dubost, F. and B. Lizet 1995. Pour une approche ethnologique du paysage. In C. Voisenat (ed.) Paysage au pluriel: pour une approche ethnologique des paysages. Paris: Editions de la Maison des Sciences de l'Homme. Pp. 225-240.

Fleury, A. and A. Mollard 1976. Agriculture, système social et environnement. Grenoble: Université des Sciences Sociales de Grenoble.

Gatti, A.M., and G. Puggioni 1998. Storia della popolazione dal 1847 a oggi. In L. Berlinguer and A. Mattone (ed.) La storia d'Italia. Le regioni dall'Unità a oggi. La Sardegna, Torino: Einaudi. Pp. 1039-1079.

Heatherington, T. 2010. Wild Sardinia: indigeneity and the global dreamtimes of environmentalism. Seattle: Washington University Press.

Heynen, N., M. Kaika and E. Swyngedouw 2006. Urban political ecology: politicizing the production of urban natures. In N. Heynen, M. Kaika and E. Swyngedouw (eds.) In the nature of cities: urban political ecology and the politics of urban metabolism. London: Routledge. Pp. 1-20.

Ingold, T. and J. L. Vergunst (eds.) 2008. Ways of walking: ethnography and practice on foot. Farnham: Ashgate.

Koensler A. and C. Papa 2013. Introduction: beyond anthropocentrism, changing practices and the politics of 'nature.' Journal of Political Ecology 20: 286-294.

Lascoumes, P. 1994. L'éco-pouvoir: environnements et politiques. Paris. Editions de la Découverte.

Lefebvre, H. 1991. The production of space. Oxford: Basil Blackwell.

Lenclud, G. 1995. Ethnologie et paysage. In C. Voisenat (ed.) Paysage au pluriel: pour une approche ethnologique des paysages. Paris: Editions de la Maison des Sciences de l'Homme. Pp. 7-17.

Lőrinczi, M. 2002. Il libro del fenicottero. Immagini della "Gente Rossa" nelle lingue e nelle arti. Cagliari: AM\&D. 
Low, S., D. Taplin and S. Scheld 2005. Rethinking urban parks: public space and cultural diversity. Austin: University of Texas Press.

Masala, F. 1994. Architetture nella città del sale. In S. Pira, F. Masala, M. Del Piano (eds.) La città del sale. Cagliari: STEF. Pp. 25-38.

Milton, K. 2002. Loving nature: towards an ecology of emotion. London: Routledge.

Mori, A. 1950. Le saline della Sardegna. Napoli: Memorie di Geografia economica.

Mori, A. 1970. La Sardegna. Torino: UTET.

Ojeda Rivera, J. F. 1983. Organization del territorio en Doñana y su entorno proximo (Almonte). Siglos $X V I I I-X X$. Madrid: Ministerio de Agricoltura.

Ortu, G.G. 2011. Genesi e produzione storica di un paesaggio: Quartu Sant'Elena. Cagliari: CUEC.

Picon, B. 1988. L'espace et le temps en Camargue. Arles: Actes Sud.

Piermattei, S. 2013. Local farmers vs. environmental universalism: conflicts over nature conservation in the Parco Nazionale dei Monti Sibillini, Italy. Journal of Political Ecology 20: 306-317.

Pira, S. 1994. Molentargius, saline, Poetto: istituzioni, edifice e tecnologie in epoca moderna. In S. Pira, F. Masala, M. Del Piano (eds.) La città del sale. Cagliari: STEF. Pp. 15-24.

Pira, S. 2004. Cagliari città del sale: immagini di Cagliari tra Ottocento e Novecento. In G.G. Ortu (ed.) Cagliari tra passato e futuro. Cagliari: CUEC. Pp. 327-338.

Principe, I. 1981. Le città nella storia d'Italia. Cagliari. Roma-Bari: Laterza.

Ruddle, K. and W. Manshard, W. 1981. Renewable natural resources and the environment. New York: United Nations University.

Ruju, S. 1998. Società, economia, politica dal secondo dopoguerra a oggi (1944-98). In L. Berlinguer and A. Mattone (ed.) La storia d'Italia. Le regioni dall'Unità a oggi: La Sardegna. Torino: Einaudi. Pp. 775992.

Sanna, A. 2004. Cagliari e il suo contado. In G.G. Ortu (ed.) Cagliari tra passato e futuro. Cagliari: CUEC. Pp. 377-386.

Settis, S. 2010. Paesaggio costituzione cemento: la battaglia per l'ambiente contro il degrado civile. Torino: Einaudi.

Siniscalchi, V. 2002. "Patrimoine naturel" et "patrimoine culturel" dans le Parc National des Ecrins (France): nouvelles représentations des territoires "protégés". Europaea 1-2: 303-317.

Sistu, G. and C. Perelli 2011. La transizione paesaggistica del sistema ferroviario della Sardegna. In F. Lai and N. Breda (eds.) Antropologia del «Terzo paesaggio», Roma: CISU. Pp. 97-130.

Soja, E.W. 1989. Post modern geographies: the reassertion of space in critical social theory. London: Verso.

Soja, E.W. 1996. Thirdspace: journeys to Los Angeles and other real-and-imagined places. London: Wiley Blackwell.

Strassoldo, R. 1993. Le radici dell'erba. Sociologia dei movimenti ambientali di base. Napoli: Liguori.

TCI, 1918. Guida d'Italia del Toring Club Italiano: Sardegna. Milano: Touring Club Italiano.

TCI, 1954. Attraverso l'Itali: Sardegna. Milano: Touring Club Italiano.

Turano, G. 2011. Il segno di Zedda. L'Espresso August 18: 58-60.

West, P., Igoe, J. and Brockington, D. 2006. Parks and peoples: the social impact of protected areas. Annual Review of Anthropology 35: 251-277.

Ythier, B. 1995. Espace rural, paysage et patrimoine. Les terrasses de Bresle en Auvergne. In C. Voisenat (ed.) Paysage au pluriel: pour une approche ethnologique des paysages. Paris: Éditions de la Maison des Sciences de l'Homme. Pp. 185-194. 


\begin{abstract}
The re-use and the domestication of nature in abandoned areas is becoming a theme of increasing relevance in European (and Italian) public debate. This article uses Gilles Clément's concept of 'third landscape' to understand the transformation of an urban salt works into a public park. Salt production in Cagliari (Sardinia, Italy) was suspended in 1984 because of pollution from urban sewage. Some years after abandonment, the state salt works eventually became a public park. People frequented the area before its establishment and eventually the salt works became a place for running, canoeing, walking, biking, birdwatching and other outdoor activities. The article shows how this abandoned area became a park and heritage site, though stakeholder support. It analyzes the local discourse that continues to represent and protect the area as 'green,' where nature can be enjoyed, despite its industrial heritage.
\end{abstract}

Keywords: salt works, wetlands, coastal parks, European coastal cities, Sardinia

\title{
Résumé:
}

La réutilisation et la domestication de la nature dans les zones abandonnées est devenue un sujet d'importance croissante. Cet article, à partir du concept de le "Tiers paysage" de Gilles Clément, aborde le sujet de la transformation d'une zone industrielle dans un parc public. La production de sel à Cagliari (capitale de la Sardaigne) a été suspendue en 1984 en raison de la pollution urbaine. Après l'abandon de la zone a été transformée en un parc public. La population de Cagliari et d'autres villes voisines, fréquentait le lieu avant même de l'établissement du parc. Ainsi, bien qu' abandonnés en tant que lieu de production de sel les marais salants etaient utilisées comme un endroit pour courir, marcher, faire du vélo et du canoë. Cet article analyse le discours locale qui réprésente cette zone comme un espace «vert» dans le milieu de la ville où on peut rejouir de la «nature».

Mots clés: Paysage, parcs, milieu urbain, salines, zones humides, Sardaigne

\section{Riassunto:}

Il riuso e la domesticazione della natura nelle aree abbandonate è diventato un tema di rilevanza crescente. Questo articolo, a partire dal concetto di Terzo paesaggio di Gilles Clément, tratta della trasformazione di un'area industriale in un parco pubblico. La produzione di sale a Cagliari (capoluogo della Sardegna) è stata sospesa nel 1984 a causa dell'inquinamento urbano. In seguito all'abbandono, l'area è stata trasformata in un parco pubblico. La popolazione di Cagliari e delle altre città vicine, frequentava l'area anche prima dell' istituzione del parco. Così le saline sebbene abbandonate erano un luogo per correre, camminare, andare in bicicletta e canoa. Questo articolo analizza il discorso locale che presenta quest'area come uno spazio "verde" nel mezzo della città, dove è possibile godere della "natura".

Parole chiave: paesaggio, parchi, ambienti urbani, saline, zone umide, Sardegna 